\title{
Expression of Molecular Biomarkers in Primary Breast Tumors Implanted into a Surrogate Host: Increased Levels of Cyclins Correlate with Tumor Progression
}

\author{
G. Wani, ${ }^{*}$ I. Noyes, ${ }^{\dagger}$ G. E. Milo, ${ }^{\dagger}$ and S. M. D'Ambrosio* \\ Departments of ${ }^{*}$ Radiology and ${ }^{\dagger}$ Medical Biochemistry, College of \\ Medicine, Ohio State University, Columbus, Ohio, U.S.A.
}

\begin{abstract}
Background: The overexpression or amplification of tumor suppressor and proto-oncogenes are important factors in the progression of breast cancer. Recent attention has focused on the cyclin genes, whose involvement in signal transduction pathways regulate cell cycle progression. The amplification of the cyclins D1 and D3 genes usually leads to loss of normal growth control and is thought to play an important growth regulatory role in tumor development and progression. In this report, we investigate the association of altered cyclin expression with other prognostic indicators (histological grade, lymph node status, estrogen receptor, p53, and c-erbB-2) in the progression of human breast cancer.
\end{abstract}

Materials and Methods: Surgical tumor specimens were obtained from 16 breast tubular ductal, and invasive ductal carcinomas and grafted onto gnotobiotic nude (nu/nu) mice. The expression diversity and distribution of the localization of the protein products of the c-erbB-2, cyclins D1 and D3, p53, and estrogen receptor were characterized immunohistochemically and the results in the original tumor $\left(\mathrm{T}_{\mathrm{o}}\right)$ were compared with those in the tumors that developed in nude mice $\left(T_{1}\right)$ xenografts.

Results: The $\mathrm{T}_{0}$ tumors exhibited a diversity of cellular morphology in the tumor matrix and diversity in expres- sion of these proteins. These specific changes were also preserved in the $T_{1}$ tumors. Whereas $67 \%$ of the $T_{1}$ tumors exhibited high numbers of estrogen receptorpositive nuclei, only $50 \%$ of these tumors grew when grafted onto nude mice. The histological grade (14/15 were $\mathrm{G} 2$ to G3) and metastatic malignancy in the lymph nodes $(10 / 15)$ did not appear to be related to tumor growth in the nude mouse. There was no relationship between those tumors which exhibited high percentages of c-erbB-2- and p53-positive cells and growth in nude mice. A strong association $(p<0.001)$ was observed between the overexpression of cyclin $\mathrm{Dl}$ transcripts in the $T_{0}$ tumors and the continued growth of the $T_{1}$ tumors in nude mice. In the $\mathrm{T}_{1}$ tumors, both cyclins $\mathrm{Dl}$ and D3, estrogen receptor, and p53 were observed in $49 \%$ to $86 \%$ of the cells of the $T_{1}$ tumors examined; the number of cells expressing c-erbB-2 protein varied widely in these tumors.

Conclusions: The results indicate that the tumor matrix exhibits a diversity in the level of phenotypic expression of genes involved in cellular growth of breast tumors in both the $\mathrm{T}_{0}$ or $\mathrm{T}_{1}$ host environment. Changes in cyclin activity appear to correlate with the vigorous level of breast tumor growth and progression.

\section{INTRODUCTION}

Many of the concepts concerning tumor progression in breast cancer have been developed from the analysis of fresh tumors or from using cell

Address correspondence and reprint requests to: S. M. D'Ambrosio, Rm. 103, Wiseman Hall, 400 W. 12th Avenue, Columbus, OH 43210, U.S.A. Tel: 614-292-9375; Fax: 614-292-7237; e-mail: dambrosio.1@osu.edu. lines derived from tumors. Human tumor xenografts in nude mice represent another important model for studying the molecular and cellular processes involved in tumor progression. Many different types of human malignant and nontumor tissues have been successfully transplanted onto nude mice without rejection (1-6). This model is similar to the in situ environment and 
preserves many of the original histochemical and biological characteristics of the original tumor. The model also allows expansion of very small biopsy material for long-term and repeated studies. However, the success rate for tumor "takes" in nude mice varies considerably among the different types of carcinomas $(2,3,7,8)$. In breast, the successful rate for xenografting of tumor tissue is low $(6 \%$ to $30 \%)(2,7,8)$, whereas that of xenografting tumor cells has been reported to be as high as $69 \%(1,6,9,10)$. Other differences in breast xenograft takes appear related to the location of the graft, whether the fat pad is subcutaneous or mammary (8), and co-injection with Matrigel (9). These systems have yielded important insights into breast cancer progression, hormonal responses, and the expression of various oncogene and tumor suppressor genes.

Breast cancer, like many other cancers, is a clinically heterogeneous disease, which often makes diagnosis and treatment difficult. Little is known about the cellular and molecular events involved in the development and progression of this disease. Increasing evidence demonstrates the importance of tumor suppressor and protooncogenes in the progression of breast cancer. The overexpression or amplification of two of these genes, c-erbB-2 and $p 53$, has been reported in $20 \%$ to $53 \%$ of breast carcinomas and is usually associated with the more aggressive tumors with poor prognosis (11-17). Recently, attention has been focused on cyclin genes, whose involvement in signal transduction pathways regulates cell cycle progression (18-22). Among the many different cyclin genes, cyclins Dl and D3 are critical for controlling the movement of cells from $G_{1}$ into the $S$ phase of the cell cycle. Amplification of these genes usually leads to loss of normal growth control, and thus it is thought to play an important growth regulatory role in tumor development and progression. Cyclin Dl and D3 are overexpressed in $10 \%$ to $80 \%$ of human breast cancers (22-25). Other studies suggest that there may be interrelations between cyclin Dl the other prognostic indicators, i.e., estrogen receptor, p53, and c-erbB-2 of breast cancer.

In this study, we examined immunohistochemically the patterns of cyclins D1 and D3, estrogen receptor, p53, and c-erbB-2 expression in fresh $\left(\mathrm{T}_{0}\right)$ and xenografted $\left(\mathrm{T}_{1}\right)$ breast tumor tissues. These studies were conducted to determine which of these factors favor their xenograft development and growth in nude mice. Our studies indicate a strong association between the overexpression of cyclin $\mathrm{Dl}$ in the $\mathrm{T}_{0}$ tumor and progression of the $T_{1}$ tumor in the nude mouse.

\section{MATERIALS AND METHODS}

Normal human breast and breast tumor tissues were obtained from Ohio State University Hospitals through the Tissue Procurement Service (OSUTPS) and the Cooperative Human Tissue Network (CHTN) at the Ohio State University Comprehensive Cancer Center. Tumor tissues were obtained from women undergoing mastectomy or lumpectomy for a confirmed diagnosis of breast carcinoma. Three- to four-week-old nude mice (nu/nu, NIH-Swiss background) were used as surrogate hosts for breast xenografts $(4,26)$. All the primary and secondary antibodies were obtained from Novocastra, U.K. Estradiol pellets and all other chemicals were obtained from Sigma Chemical Company.

\section{Establishment of Breast Tumor Tissue Xenograft}

One week prior to the establishment of the breast tumor xenograft, the nude mice were splenectomized as previously described $(3,4,27,28)$. At the time of splenectomy, a pellet of $0.36 \mathrm{mg} 17$ $\beta$-estradiol pellet or a placebo was implanted subcutaneous in one set of mice. The other set received no estradiol, for comparison of the effect of estrogen. Following the surgical excision of the breast tumor tissue $\left(\mathrm{T}_{0}\right)$, tissue was placed in $5 \mathrm{ml}$ of sterile Hanks balanced salt solution (HBSS) ( $\mathrm{pH} \mathrm{7.0)}$ and transported to the laboratory on ice. The breast tumor tissues were freed from fat and connective tissue and minced into 1 - to $2-\mathrm{mm}^{3}$ pieces for xenograft implantation. To establish the breast tumor tissue xenograft $\left(T_{1}\right)$, the mice were placed under general anesthesia with $50 \mathrm{ng}$ per $\mathrm{ml}$ of sodium pentobarbital and placed on the right side of the body; four small, $1.5-\mathrm{cm}$ dorsal-ventral incisions were made through the skin parallel to the ribs on the back of the mouse. The breast tumor pieces were inserted subcutaneously into each biopsy site. Each graft was sutured in place with three absorbable sutures. The individual grafts were then covered with a thin layer of Bacitracin ointment. At the same time, when sufficient amounts of tumor tissue were available, a piece of the original breast tumor tissue was fixed in $4 \%$ paraformaldehyde in phosphate-buffered saline (PBS) overnight at $4^{\circ} \mathrm{C}$. This original tumor tissue sam- 
ple was used for later comparison with the xenograft tissue obtained from the nude mice. All mice were examined twice a week for tumor growth at the site of the xenograft and other noninvolved subcutaneous sites. The tumor size was determined by vernier calipers. Every 2 to 3 weeks, tumors were surgically removed from the nude mice and the incision site closed by suturing. These tissues were fixed in $4 \%$ paraformaldehyde overnight at $4{ }^{\circ} \mathrm{C}$. The original and xenograftfixed breast tumor tissue was then dehydrated, embedded with molten paraffin, cut into $8-\mu \mathrm{m}$ microtome sections, and mounted on poly-L-lysine-coated slides as previously described for immunohistochemical analysis (29).

\section{Immunohistochemical Studies}

Immunohistochemical detection of cyclin (D1, D3), estrogen receptor (ER), p53, and C-erbB-2 (erb) proteins was performed in the $\mathrm{T}_{0}$ tumor tissue when available, and the $T_{1}$ tumor tissue in the nude mice. Paraformaldehyde-fixed $8-\mu \mathrm{M}$ tissue sections were mounted on poly-L-lysinecoated slides and processed for immunohistochemical studies. Tissues were deparaffinized in xylene, dehydrated, and washed with PBS. In tissue sections the antigen was unmasked by heating in a microwave oven (Samsung compact series MW2000U) at maximum power for 15 min in $0.01 \mathrm{M}$ citrate buffer (pH 6.0) (30). After $30 \mathrm{~min}$ at room temperature, the sections were washed with PBS and incubated with normal serum for $30 \mathrm{~min}$ at room temperature. The sections were incubated overnight at $4^{\circ} \mathrm{C}$ with primary antibodies, estrogen receptor (NCL-ERLH2, 1:500), cyclin Dl (NCL-cyclin-D1, l:200), cyclin D3 (NCL-cyclin-D3, 1:200), p53 (PAB $1801,1: 500)$, and c-erbB-2 oncoprotein (NCLCB1 1, 1:500). These antibody dilutions were optimal for visualizing the specific color and minimizing background in the tissue sections. Tissue sections incubated without primary antibody and sections from other tissues not expressing these antigens served as negative controls. Following incubation, the sections were washed twice with PBS (7.2), and a second incubation with biotin-conjugated anti-mouse secondary antibody (Vector Laboratories, Burlington CA) was carried out for $30 \mathrm{~min}$ at room temperature. After three more washes with PBS, sections were incubated with prepared ABC-AP alkaline phosphate complex (ABC-AP, Vectastain Kit, Vector) for $45 \mathrm{~min}$ at room temperature. The sections were washed with PBS and AP-9.0 buffer (150
$\mathrm{mM}$ TrisHCl, $150 \mathrm{mM} \mathrm{NaCl}, 50 \mathrm{mM} \mathrm{MgCl}$, $\mathrm{pH}$ 9.5). The color was developed by incubation in AP-9.5 containing $0.33 \mathrm{mg} / \mathrm{ml}$ nitroblue tetrazolium chloride (NBT), $0.17 \mathrm{mg} / \mathrm{ml}$ 5-bromo-1 chloro-3-indolyl phosphate (BCIP), and 0.26 $\mathrm{mg} / \mathrm{ml}$ levamisole for $25 \mathrm{~min}$. The reaction was terminated by rinsing three times in $100 \mathrm{ml}$ of distilled water. The tissue sections were then dehydrated in a graded series of ethanol from $70 \%$ to $100 \%$ and coverslipped in permount medium. Staining was viewed and photographed using a bright-field microscope. Cyclin Dl and D3, ER, and p53 staining was confined to the nucleus; c-erbB-2 was specific to the membrane. Cellular staining was graded as negative (same as a negative control), moderate, or strong. Only the cells exhibiting moderate or strong staining were scored positive. Immunohistochemical evaluation was performed by counting the number of positive and negative staining cells in four different areas ( 100 cells per area) of the same section and different sections from which the percent cells staining positive was calculated.

\section{Statistical Analysis}

Results are expressed as the mean \pm standard error of the mean (SEM) and were analyzed for significance using SPSS software. Paired sample $t$-Test and Pearson correlation coefficients were used to determine the relationship, if any, between immunohistological markers. A $p<0.05$ was considered to be statistically significant.

\section{RESULTS}

\section{Characteristics of Human Breast Cancers}

Tumor $\left(\mathrm{T}_{0}\right)$ portions from 16 primary breast carcinomas were transplanted subcutaneously to nude mice. Of these, six $\mathrm{T}_{0}$ tumors $(38 \%)$ grew at the site of transplant to form $T_{1}$ tumors. The surgical pathological characteristics of the $T_{0}$ tumors are indicated in Table 1 . The $\mathrm{T}_{0}$ tumor types included various forms of ductal, malignant, and invasive carcinomas, and none appeared to correlate with the frequency of tumor takes in nude mice. The histological grade, which includes tubule formation, nuclear pleomorphism, and mitotic scores, was intermediate (G2) to high (G3) in 14 of 16 tumors. There did not appear to be a relationship between the histological grade and tumor take on the nude mouse. There also did not appear to be a relationship between meta- 
TABLE 1. Pathological characteristics of the $T_{0}$ human breast tumors

\begin{tabular}{|c|c|c|c|c|c|c|}
\hline Tissue & $\mathbf{A g e}^{a}$ & $\begin{array}{c}\text { Estrogen } \\
\text { Receptor }^{a, b}\end{array}$ & Tumor Type ${ }^{a}$ & Grade $^{c}$ & $\begin{array}{c}\text { Lymph } \\
\text { Node }^{d}\end{array}$ & $\begin{array}{c}\text { Xenograft } \\
\text { Growth }\end{array}$ \\
\hline 144 & 72 & Positive & $\begin{array}{l}\text { Focal infiltrating ductal carcinoma } \\
\text { with extensive intraductal } \\
\text { component }\end{array}$ & G2. & $\mathrm{N}$ & + \\
\hline 111 & 74 & n.d. & Tubular and ductal carcinoma & G3 & $\mathrm{Y}$ & + \\
\hline 037 & 76 & Positive & $\begin{array}{l}\text { Infiltrating mammary carcinoma } \\
\text { with features of variant lobular } \\
\text { carcinoma }\end{array}$ & G2 & $\mathrm{N}$ & + \\
\hline 202 & 84 & 85 & Infiltrating adenocarcinoma & $\mathrm{G} 2 / \mathrm{G} 3$ & $\mathrm{~N}$ & + \\
\hline 195 & 84 & 85 & Invasive ductal carcinoma & G2 & $\mathrm{Y}$ & + \\
\hline 432 & 85 & Negative & Residual invasive ductal carcinoma & G3 & $\mathrm{N}$ & + \\
\hline 118 & 34 & n.d. & Invasive carcinoma & G3 & n.d. & - \\
\hline 003 & 40 & 10 & Invasive ductal carcinoma & G3 & $\mathrm{N}$ & - \\
\hline 089 & 48 & Negative & Invasive ductal carcinoma & G3 & $\mathrm{Y}$ & - \\
\hline 062 & 48 & n.d. & $\begin{array}{l}\text { Poorly differentiated infiltrating } \\
\text { ductal carcinoma }\end{array}$ & G1 & $\mathrm{Y}$ & - \\
\hline 075 & 53 & n.d. & Infiltrating ductal carcinoma & G2 & $\mathrm{Y}$ & - \\
\hline 222 & 58 & Negative & Invasive carcinoma & $\mathrm{G} 2$ & $\mathrm{Y}$ & - \\
\hline 148 & 64 & 73 & Invasive and ductal carcinoma & $\mathrm{G} 2 / \mathrm{G} 3$ & $\mathrm{~N}$ & - \\
\hline 198 & 71 & 72 & Invasive adenocarcinoma & Gl & $\mathbf{N}$ & - \\
\hline 337 & 85 & 85 & Infiltrating ductal carcinoma & G3 & $\mathrm{Y}$ & - \\
\hline 155 & 89 & Positive & Infiltrating ductal carcinoma & G2 & $\mathrm{Y}$ & - \\
\hline
\end{tabular}

${ }^{a}$ This information was obtained from surgical and pathological records from each case and was supplied anonymously by the Ohio State University Tissue Procurement Service.

${ }^{b}$ Estrogen receptor values (\% positive).

${ }^{c}$ Grade $=$ tubule formation, nuclear pleomorphism, mitotic scores.

${ }^{d}$ Lymph node $=$ indication of metastatic malignancy in lymph node.

${ }^{e}$ Xenograft growth was positive $(+)$ when a nodule at the site of the transplant was visible within 2 weeks. Growth was negative $(-)$ when the tumor was absorbed by the host.

n.d., not determined or no information available.

static malignancy in the lymph nodes and tumor take, since $66 \%$ of the tumors in both the xenograft-positive and -negative groups exhibited lymph node involvement.

Eight of these tumors exhibited high numbers of cells (i.e., positive or $>70 \%$ ) with estrogen receptor-positive nuclei, while levels were very low $(<20 \%)$ in three tumors. In four tumors, no pathological information was available on estrogen receptor status. Our immunohistochemical analysis of two of these tumors indicated that tumor 118 was negative for estrogen receptor (Fig. 1, neg. $\mathrm{T}_{0}$ ), and tumor 003 showed that approximately $39 \%$ of the tumor cells immunoreacted with antibody to estrogen receptor protein (Table 2 ). Immunohistochemical analysis also indicated levels of estrogen receptor-positive nuclei similar to the pathological reports in tumors 037, 195, and 337. The levels in tumor 003 were significantly higher, 39 versus 10 , than the pathological reports. In all of the tumors positive for estrogen receptor, the cells immunoreactive for this protein were localized in the ducts (Fig. 1, pos. $T_{0}$ ). This localization of estrogen receptor-positive cells was maintained in the $T_{1}$ tumor in nude mice (Fig. 1, pos. $\mathrm{T}_{1}$ ). Overall, $67 \%$ of the $T_{0}$ tumors exhibited high numbers of cells with estrogen receptor-positive nuclei. Only $50 \%$ of these estrogen receptor-positive $\mathrm{T}_{0}$ tumors grew as $\mathrm{T}_{1}$ tumors in nude mice. There was not a statistically significant $(p>0.05)$ association between the levels of estrogen receptor pro- 


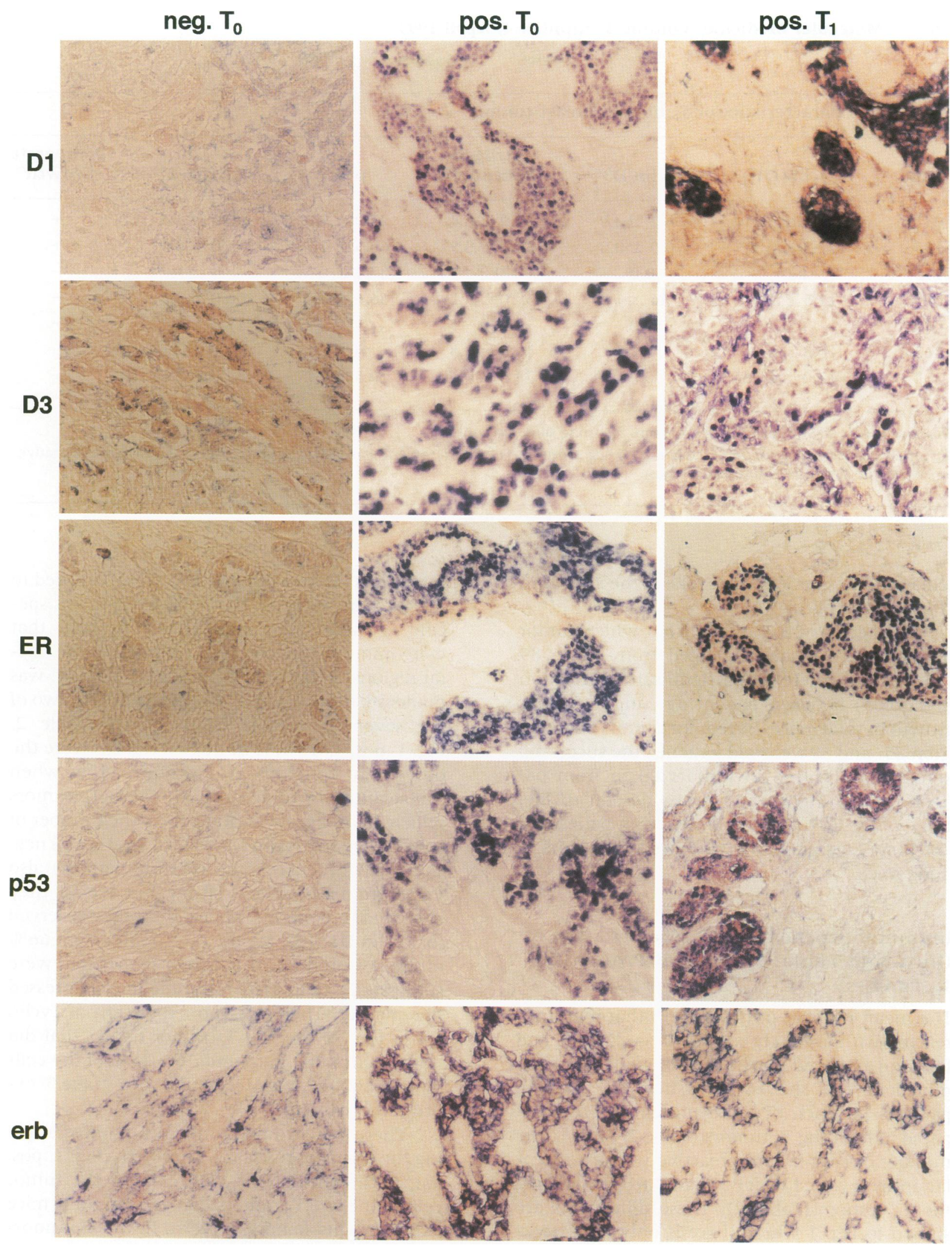

FIG. 1. Immunohistochemical detection of cyclins D1 and D3, estrogen receptor, p53, and c-erbB-2 in $T_{0}$ and $T_{1}$ tumors

Representative sections (neg. $T_{0}$ ) are illustrated from $T_{0}$ tumor 118 , which were undetectable for cyclins D1 and D3, and undetectable for estrogen receptor; sections from tumor 089 were undetectable for p53, and tumor 062 exhibited $13 \%$ positive cell staining for c-erbB-2. Tissue sections from the ductal carcinoma $\mathrm{T}_{0}$ tumor 195 are shown representing positive (pos. $\mathrm{T}_{0}$ ) staining to all the antigens. The staining patterns of tissue sections from tumor 195 (pos. $\mathrm{T}_{1}$ ) show staining patterns similar to that observed in the $\mathrm{T}_{0}$ tumor. Notice the strong nuclear staining of cells positive for cyclins D1 and D3, estrogen receptor, and p53, and membrane-specific staining for c-erbB-2 protein. D1, cyclin D1; D3, cyclin D3; ER, estrogen receptor; erb, c-erbB-2; neg., negative; pos., positive. 
TABLE 2. Characteristics of $\mathbf{T}_{\mathrm{o}}$ human breast tumors

\begin{tabular}{|c|c|c|c|c|c|c|}
\hline Tissue & Cyclin DI ${ }^{a}$ & Cyclin $\mathbf{D 3}^{a}$ & $\begin{array}{c}\text { Estrogen } \\
\text { Receptor }^{a}\end{array}$ & $\mathbf{p} 53^{a}$ & C-erbB-2 ${ }^{a}$ & $\begin{array}{c}\text { Xenograft } \\
\text { Growth }^{b}\end{array}$ \\
\hline 037 & $76.0 \pm 0.2$ & $66.2 \pm 2.9$ & $87.0 \pm 0.4$ & $75.0 \pm 0.6$ & $80.0 \pm 2.5$ & + \\
\hline 195 & $77.3 \pm 0.5$ & $70.0 \pm 0.5$ & $84.5 \pm 0.9$ & $60.5 \pm 3.2$ & $75.0 \pm 0.3$ & + \\
\hline 118 & 0.0 & 0.0 & 0.0 & $57.5 \pm 0.5$ & $19.3 \pm 1.7$ & - \\
\hline 003 & $11.5 \pm 1.4$ & $46 \pm 1.2$ & $39.0 \pm 5.2$ & $66.6 \pm 3.0$ & $56.0 \pm 2.8$ & - \\
\hline 089 & 0.0 & 0.0 & 0.0 & 0.0 & $15.5 \pm 1.7$ & - \\
\hline 062 & $10.8 \pm 1.2$ & 0.0 & $16.0 \pm 2.8$ & 0.0 & $13.0 \pm 2.1$ & - \\
\hline 337 & $12.0 \pm 2.3$ & 0.0 & $74.0 \pm 0.6$ & $10.5 \pm 0.2$ & $52.0 \pm 2.0$ & - \\
\hline
\end{tabular}

${ }^{a}$ Percent of cells \pm SEM exhibiting moderate to strong stain for antibody.

${ }^{b} \mathrm{~T}_{1}$ tumor growth was positive $(+)$ when a nodule at the site of the transplant was visible within 2 weeks. Growth was negative $(-)$ when the tumor was absorbed by host.

tein in the $\mathrm{T}_{0}$ tumor and the take of the xenograft $\left(\mathrm{T}_{1}\right)$ in nude mice.

The ages of the patients from which tumor samples were obtained ranged from 34 to 89 years of age. There was a significant correlation $(p<0.05)$ between patient age and $\mathrm{T}_{1}$ tumor growth in nude mice. Except for tumors obtained from 85- and 89-year-old patients, the successful xenografts occurred in tumors taken from patients in the eighth and ninth decade of life. None of the $T_{0}$ tumors obtained from patients of less than 72 years of age produced $T_{1}$ tumors in nude mice.

\section{Immunohistochemical Characterization of Onco- and Tumor Suppressor Proteins in $\mathbf{T}_{\mathbf{0}}$ Tumors}

The mean number of tumor cells that immunoreacted with antibody specific to cyclins $\mathrm{Dl}$ and D2, and p53 and c-erbB-2 proteins was determined in 7 of the $16 \mathrm{~T}_{0}$ tissues. The staining patterns for each of these proteins were compared in both the $\mathrm{T}_{0}$ tumors (Table 2, Fig. 1). The number of cells immunoreactive with a particular antigen varied widely, from 0 to $87 \%$ among the $\mathrm{T}_{0}$ tumors (Table 2 ). These differences are shown in Fig. 1 where there is only faint background staining of some $\mathrm{T}_{0}$ tumors (Fig. 1, neg. $\mathrm{T}_{0}$ ), compared with intense cellular localization of stain in other $\mathrm{T}_{0}$ tumors (Fig. 1 , pos. $\mathrm{T}_{0}$ ). In those tumors that were immunoreactive to an antibody to a particular gene product, the staining patterns were characteristic of the localization of the protein in the cell. For example, stain for cyclins D1 and D3, and p53 were localized to the nucleus, whereas that for c-erbB-2 was specific to the cellular membrane. The cells that were immunoreactive were confined to the ductal regions of the tumor. Cyclin Dl staining was moderate to strong in $>76 \%$ of the cells in two of the seven $\mathrm{T}_{0}$ tumors characterized (Table 2, Fig. 1, pos. $\mathrm{T}_{0}$ ). These same two tumors were the only ones from this group which grew when transplanted in nude mice. In those $\mathrm{T}_{0}$ tumors which did not grow in nude mice, the number of cells expressing cyclin D1 was $<12 \%$ (Fig. 1 , neg. $\mathrm{T}_{0}$ ). With cyclin $\mathrm{D} 3$, the staining patterns also varied from moderate to strong, but overall, they appeared to be more intense than that observed for cyclin Dl (Fig. 1, pos. $\mathrm{T}_{0}$ ). Greater than $66 \%$ of the cells in the two $\mathrm{T}_{0}$ tumor tissues that were successfully xenografted in nude mice expressed this marker. There was no expression of cyclin D3 in four of the five $T_{0}$ tumor tissues that did not take in nude mice and only $46 \%$ of the cells in tissue 003, which also did not "take," expressed cyclin $\mathrm{D} 3$.

There was strong staining of tumor cells lining the ducts for nuclear p53 protein (Fig. 1, pos. $\mathrm{T}_{0}$ ). Greater than $60 \%$ and $75 \%$ of the tumor cells in the two $T_{0}$ tumors that grew in nude mice exhibited this staining pattern. In the $\mathrm{T}_{0}$ tumors that did not grow in nude mice, the number of cells exhibiting $\mathrm{p} 53$ protein varied from 0 (Fig. 1, neg. $\mathrm{T}_{0}$ ) to $67 \%$. The staining patterns for cerbB-2 protein were strong and more homogeneous among the tumor cells (Fig. 1, pos. $\mathrm{T}_{0}$ ). The number of cells producing c-erbB-2 protein was highest $(75 \%$ and $80 \%$ positive cells) in the 
TABLE 3. Pearson correlation coefficients between markers in $T_{0}$ tumors and growth of $T_{1}$ tumors in nude mice

\begin{tabular}{|c|c|c|c|c|c|}
\hline & $\begin{array}{c}\text { Cyclin } \\
\text { D3 }\end{array}$ & $\begin{array}{l}\text { Estrogen } \\
\text { Receptor }\end{array}$ & c-erbB-2 & p53 & $\begin{array}{c}\text { Xenograft } \\
\text { Growth }\end{array}$ \\
\hline Cyclin D1 & $0.885^{a}$ & $0.822^{a}$ & $0.844^{a}$ & 0.583 & $0.989^{b}$ \\
\hline Cyclin D3 & & 0.727 & $0.886^{a}$ & $0.783^{a}$ & $0.862^{a}$ \\
\hline Estrogen receptor & & & $0.976^{b}$ & 0.438 & 0.752 \\
\hline c-erbB-2 & & & & 0.689 & $0.796^{a}$ \\
\hline p53 & & & & & 0.596 \\
\hline $\begin{array}{l}{ }^{a} p<0.05 \\
{ }^{b} p<0.001\end{array}$ & & & & & \\
\hline
\end{tabular}

two tumors that successfully grew in nude mice. The number of cells immunoreactive for c-erbB-2 protein in $\mathrm{T}_{0}$ tumors that did not grow in nude mice varied markedly from $13 \%$ (Fig. 1, neg. $\mathrm{T}_{0}$ ) to $56 \%$ positive cells.

A number of correlations were demonstrated between markers in the tumor tissues (Table 3). A statistically significant positive correlation $(p<$ 0.001 ) was demonstrated between $\mathrm{T}_{0}$ tumor tissues with high levels of cyclin Dl protein and growth of the $T_{1}$ tumor in nude mice. There was a positive correlation $(p<0.05)$ between xenograft growth and the levels of cyclin D3 and c-erbB-2 proteins. The $\mathrm{T}_{0}$ tumors with a high number of cells staining for cyclin Dl protein also correlated $(p<0.05)$ with staining patterns for estrogen receptor and c-erbB-2 proteins. Levels of c-erbB-2 in the tumor tissue correlated with cyclin D3 $(p<0.05)$ and estrogen receptor $(p<0.001)$ levels. P53 levels only correlated with those of cyclin D3 $(p<0.05)$.

\section{Characteristics of $T_{1}$ Tumors}

Initially, following subcutaneous transplantation of $\mathrm{T}_{0}$ tumor tissue pieces in nude mice, palpable $\mathrm{T}_{1}$ tumors usually develop at the site within 2 weeks. In those $T_{0}$ tumors that did not take in nude mice, the $T_{1}$ tumor tissue was quickly absorbed by the host. Successful xenografts exhibited an exponential growth phase between 2 and 9 weeks, during which time they were harvested for immunohistochemical characterization. $\mathrm{T}_{0}$ tumor tissue from Patient 003 was transplanted into the mammary fat pad of the nude mice as previously described for orthotopic transplant (8). Both the tumor tissue transplanted into the fat pad and subcutaneously were absorbed within 1 week and 1 month, respectively, by the mouse. We observed a similar effect when enzymatically dispersed tumor tissue from Patient 089 was injected subcutaneously with Matrigel in nude mice as previously described (9).

Immunohistochemical studies for cyclins D1 and D3, estrogen receptor, p53, and c-erbB-2 were performed in the $T_{1}$ tumors harvested at multiple time points, 1 to 4 weeks following transplantation of the original tumor (Fig. 1, pos. $\mathrm{T}_{1}$ ). In Fig. 1, representative immunohistochemical analyses of one of the $\mathrm{T}_{1}$ tumors is compared with the $\mathrm{T}_{0}$ tumor tissue. Notice that the staining patterns in the $T_{1}$ tumor are for the most part similar to that observed in the $T_{0}$ tumor. The percentage of cells expressing cyclin D1, estrogen receptor, $\mathrm{p} 53$, and c-erbB-2 are similar in the $\mathrm{T}_{1}$ tumor (Table 4) as compared with the $\mathrm{T}_{0}$ tumor (Table 2). While the number of tumor cells staining positive for Cyclin D1 are similar for tumor 195, the staining intensity appears to be greater in the $T_{1}$ than in the $T_{0}$ tumor (Fig. 1 , pos. $T_{1}$ ). There was a decrease in the number of cells immunoreactive for cyclin D3 in tumor 195 when it was transplanted into nude mice (Tables 2 and 4; Fig. 1, pos. $\mathrm{T}_{1}$ ). The number of tumor cells immunoreactive for cyclin D3 was similar in both $T_{0}$ and $T_{1}$ tumors from Patient 037 (Table 2 and 4). The staining patterns for $\mathrm{p} 53$ and c-erbB-2 proteins were similar for the $\mathrm{T}_{0}$ and $T_{1}$ tumors (Fig. 1, pos. $T_{0}, T_{1}$ ). Cyclin Dl, estrogen receptor, and p53 were expressed in the majority of cells $(54 \%$ to $86 \%)$ in all of the $\mathrm{T}_{1}$ tumors (Table 4). Cyclin D3 was expressed in $48.5 \%$ of the cells of tissue 195, and it was highly expressed $(70 \%$ to $75 \%)$ in the cells of the other $\mathrm{T}_{1}$ tumors. Only $37 \%$ of the cells of $\mathrm{T}_{1}$ tumor 144 expressed c-erbB-2, whereas this marker was ex- 
TABLE 4. Characteristics of $T_{1}$ human breast tumors

\begin{tabular}{lccccr}
\hline Tissue & $\begin{array}{c}\text { Cyclin } \\
\text { D1 }^{a}\end{array}$ & $\begin{array}{c}\text { Cyclin } \\
\text { D3 }^{a}\end{array}$ & $\begin{array}{c}\text { Estrogen } \\
\text { Receptor }^{a}\end{array}$ & p53 $^{a}$ & C-erbB-2 $^{a}$ \\
\hline 037 & $63.0 \pm 1.8$ & $72.7 \pm 1.0$ & $86.0 \pm 1.4$ & $74.7 \pm 2.1$ & $85.2 \pm 2.7$ \\
195 & $67.5 \pm 3.5$ & $48.5 \pm 3.1$ & $79.2 \pm 1.5$ & $79.7 \pm 1.6$ & $67.0 \pm 4.2$ \\
111 & $64.75 \pm 0.7$ & $71.3 \pm 1.5$ & $74.5 \pm 0.8$ & $58.7 \pm 9.8$ & $78.5 \pm 2.4$ \\
144 & $71.5 \pm 2.6$ & $75.0 \pm 0.6$ & $79.0 \pm 2.1$ & $54.5 \pm 1.2$ & $37.0 \pm 2.5$ \\
202 & $61.5 \pm 0.3$ & $73.0 \pm 1.9$ & $62.7 \pm 1.1$ & $63.7 \pm 3.6$ & $91.5 \pm 0.3$ \\
432 & $73.7 \pm 1.2$ & $70.0 \pm 2.9$ & $77.7 \pm 0.8$ & $69.7 \pm 1.3$ & $62.2 \pm 2.6$ \\
\hline
\end{tabular}

${ }^{\text {aPercent }}$ of cells \pm SEM staining positive for antibody as described in Materials and Methods.

pressed in $62 \%$ to $91.5 \%$ of the cells in the other $\mathrm{T}_{1}$ tumors.

\section{DISCUSSION}

$\mathrm{T}_{0}$ and $\mathrm{T}_{1}$ breast tumor tissues have been used to analyze both the tumorigenic potential and molecular signals associated with tumor progression $(1,2,6-10,31)$. In these studies the development of a progressively growing tumor in a nude mouse has been used as a measure of the expression of cellular phenotypes similar to those present in human breast cancer. In this study, we compared a number of pathological and molecular parameters in the original tumor $\left(\mathrm{T}_{0}\right)$ with growth and progression of the tumor as a xenograft $\left(\mathrm{T}_{1}\right)$ in nude mice.

Our study indicates a diversity of phenotypes in both $T_{0}$ and $T_{1}$ tumors in nude mice. While this diversity of phenotypes is typical of human breast tumors, the tissue organization and molecular phenotypes observed in the $\mathrm{T}_{0}$ tumor are for the most part preserved in the $T_{1}$ tumor. This consistency in $T_{1}$ pathology also has been observed by others using breast tumors $(2,6-9,32)$. A small percentage of $T_{0}$ breast tumors take in the nude mouse, as compared with other tissues $(3,4,28)$. The histological grade or metastatic malignancy of the tumor did not appear to affect the tumor xenograft take, which suggests that tumor xenograft takes may be more related to those cells in the tumor matrix that express genes specifically associated with tumor growth.

The ability of tumor cells to continuously proliferate in vivo and in vitro is thought to be because of changes in genes that predominantly control growth and because of an enhancement of the mitotic index $(21,33,34)$. A large percent- age of breast tumors are estrogen receptor positive and require endogenous estrogen to sustain growth of the tumor. Estrogen receptor-positive tumors are usually well differentiated, responsive to anti-estrogen therapy, and have a good clinical prognosis (35-37). The observation that all of the $T_{1}$ tumors were estrogen receptor positive to approximately the same levels suggested that either the expression of this gene was important in tumor growth or that the nude mouse environment selected those tumors with this phenotype. Interestingly, endogenous estrogen was not required to sustain the growth of these $T_{1}$ tumors in the nude mouse, indicating that this was not a direct causal association in $T_{1}$ breast tumor growth. Moreover, the data indicated that there was no direct association between tumor take and estrogen receptor status of the $\mathrm{T}_{0}$ tumor, further suggesting that other factors were causally associated with the establishment and continued growth of the $T_{1}$ tumor in nude mice.

The phenotypic expression of the proliferative potential and aggressiveness of breast tumors has been associated with the increased activity of the tumor suppressor gene, $p 53$ $(9,17,38-46)$. In these studies, protein-staining patterns associated with an increase in p53 activity and other genes associated with altering the kinetics of the cell cycle usually vary from tumor to tumor and between cells within the same tumor. We also observed a similar diversity in the expression of $p 53$ gene product in the $\mathrm{T}_{0}$ tumors. This diversity was similar to that in the $\mathrm{T}_{0}$ tumors. Previous studies have indicated an excellent correlation between growth of the tumor cells injected subcutaneously with Matrigel into nude mice and strong expression of p53. Even though our sample size was small, the data were consistent and repeatable, showing a poor 
association between the presence of $\mathrm{p} 53$ protein in the $\mathrm{T}_{0}$ tumor and takes in the xenograft. This difference is probably related to the use of Matrigel, which may select for p53-positive cells from the tumor. The nude mouse may also select for cells in the $T_{0}$ tumors that contain a high number of p53-positive staining cells, since all the $\mathrm{T}$ tumors exhibited $>50 \%$ of their cells immunoreactive to the p53 antibody.

The phenotypic diversity in the expression of genes involved in both $T_{0}$ and $T_{1}$ tumor growth was also observed with c-erbB-2 oncogene. This apparently is a characteristic of this oncogene, since the increased number of cells expressing this gene has been frequently observed in other studies using tumor cell lines and tissue xenografted to the nude mice $(7,9,47-49)$. Whereas this protein has been clinically associated with aggressive growth of breast tumor and poor clinical prognosis $(7,11,47-52)$, the present data indicated that this gene product does not appear to be important in the continued growth of $T_{1}$ tumors in nude mice.

The present study suggests that cyclin Dl plays an important role in $\mathrm{T}_{1}$ tumor growth. Moreover, the increased presence of cyclin $\mathrm{D}$ proteins is strongly associated with many types of cancers, including breast $(20,22-24,53,54)$. Cyclins D1 and D3 proteins are expressed early in the $G_{1}$, and they are necessary and rate limiting in the transition through the $G_{1} / S$ gate into the S phase of the cell cycle (18-21). Aberrant expression of cyclins can lead to a loss of normal growth control. Two previous studies indicated that $29 \%$ and $81 \%$ of primary breast carcinomas overexpress cyclin D1 $(22,24)$. One of these studies (24) also indicated that cyclin D3, which controls events later in $G_{1}$, prior to S-phase entry, was overexpressed in approximately $10 \%$ of breast tumors. However, in these studies, overexpression of either cyclin D1 or D3 was observed in over $69 \%$ of breast carcinomas, which suggests that overexpression of either the Dl or D3 cyclin may be sufficient to relieve the cell of its mitogenic stimulatory requirement (55). Our studies indicated that $28 \%$ of the $\mathrm{T}_{0}$ tumors studied overexpress both cyclins D1 and D3. These tumors grew as $T_{1}$ tumors in the nude mice and continued to express high levels of cyclin D1. Whereas all the $T_{1}$ tumors expressed high levels of cyclin D 1 , all but one $T_{1}$ tumor expressed high levels of cyclin D3. In this tumor the percentage of cells expressing cyclin D3 declined from $70 \%$ in $\mathrm{T}_{0}$ to $48.5 \%$ in $\mathrm{T}_{1}$. Another tumor that expressed low levels of D 1 but high levels of D3 did not grow in $T_{1}$. These data suggest that cyclin $\mathrm{Dl}$ may be an important factor for tumor growth in the nude mouse and are consistent with the release of tumor cells from mitogenic stimulus. In conclusion, these studies indicate that there appears to be a diversity in the phenotypic expression of genes associated with the cellularity of breast tumors and that those genes involved in regulating progression through the cell cycle may be important factors in breast tumor progression.

\section{ACKNOWLEDGMENTS}

This work was supported by grants R21CA66193 (S.M.D. and G.E.M.), RO1-CA25907 (G.E.M.), and P30-CA16058 (S.M.D.) from the National Cancer Institute.

\section{REFERENCES}

1. Clarke R. (1996) Human breast cancer cell line xenografts as models of breast cancer: The immunobiologies of recipient mice and the characteristics of several tumorigenic cell lines. Breast Cancer Res. Treat. 39: 69-86.

2. Brunner N, Boysen B, Romer J, SpangThomsen M. (1993) The nude mouse as an in vivo model for human breast cancer invasion and metastasis. Breast Cancer Res. Treat. 24: 257-264.

3. Kurian P, Milo GE, Noyes I. (1992) Metabolism of benzo[a]pyrene in human skin xenografts. Cancer Biochem. Biophys. 13: 23-31.

4. Chen JC, Shuler CF, Zhang CX, Schuller DE, Milo GE. (1991) Histopathologic comparison between human oral squamous cell carcinomas and their xenografts in nude mice. Oral Surg. Pathol. 71: 457-463.

5. Price JE, Polyzos A, Zhang RD, Daniels LM. (1990) Tumorigenicity and metastasis of human breast carcinoma cell lines in nude mice. Cancer Res. 50: 717-727.

6. Price JE, Zhang RD. (1990) Studies of human breast cancer metastasis using nude mice. Cancer Metastasis Rev. 8: 285-297.

7. Giovanella BC, Vardeman DM, Williams LJ, Taylor DJ, Ipolyi PD, Greef PJ, et al. (1991) Heterotransplantation of human breast carcinomas in nude thymus mice: correlation between successful heterotransplants. Int. J. Cancer 47: 66-71.

8. Fu X, Le P, Hoffman RM. (1993) A metastic orthotopic-transplant nude-mouse model of 
human breast cancer. Anticancer Res. 13: 901-904.

9. Mehta RR, Graves JM, Warso MA, Gupta TKD. (1995) Overexpression of mutant p53 and c-erbB-2 proteins and breast tumour take in mice. Br. J. Cancer 72: 1160-1164.

10. Lewko WM, Vaghmar R, Hubbard D, Moore M, He Y-J, Chang L, et al. (1990) Cultured cell lines from human breast cancer biopsies and xenografts. Breast Cancer Res. Treat. 17: 121-129.

11. Quénel N, Wafflart J, Bonichon F, De Mascarel I, Trojani M, Durand M, et al. (1995) The prognostic value of c-erbB2 in primary breast carcinomas: A study on 942 cases. Breast Cancer Res. Treat. 35: 283-291.

12. Molina R, Jo J, Filella X, Zanon G, Pahisa J, Muñoz M, et al. (1996) C-erbB-2 oncoprotein in the sera and tissue of patients with breast cancer. Utility in prognosis. Anticancer Res. 16: 2295-2300.

13. Becker K, Dosch J, Gregel CM, Martin BA, Kaina B. (1996) Targeted expression of human $\mathrm{O}^{6}$-methylguanine-DNA methyltransferase (MGMT) in transgenic mice protects against tumor initiation in two-stage skin carcinogenesis. Cancer Res. 56: 3244-3249.

14. Horne GM, Anderson JJ, Tiniakos DG, McIntosh GG, Thomas MD, Angus B, et al. (1996) p53 protein as a prognostic indicator in breast carcinoma: A comparison of four antibodies for immunohistochemistry. $\mathrm{Br} . \mathrm{J}$. Cancer 73: 29-35.

15. Cox LA, Chen G, Lee EY-HP. (1994) Tumor suppressor genes and their roles in breast cancer. Breast Cancer Res. Treat. 32: 19-38.

16. Bosari S, Viale G. (1995) The clinical significance of p53 aberrations in human tumours. Virchows Arch. Int. J. Pathol. 427: 229-241.

17. Allred DC, Elledge R, Clark GM, Fuqua SA. (1994) The p53 tumor-suppressor gene in human breast cancer. Cancer Treat. Res. 71: 63-77.

18. Andrews BJ, Mason SW. (1993) Gene expression and the cell cycle: A family affair. Science 261: 1543-1544.

19. Boulikas T. (1994) Control of DNA replication by protein phosphorylation. Anticancer Res. 14: 2465-2472.

20. Strobl JS, Wonderlin WF, Flynn DC. (1995) Mitogenic signal transduction in human breast cancer cells. Gen. Pharmacol. 26: 16431649.

21. Wuarin J, Nurse P. (1996) Regulating S phase: CDKs, licensing and proteolysis. Cell 85: 785-787.

22. Zhang S-Y, Caamano J, Cooper F, Guo X, Klein-Szanto AJP. (1994) Immunohistochemistry of cyclin D1 in human breast cancer. Am. J. Clin. Pathol. 102: 695-698.

23. Gillett C, Smith P, Gregory W, Richards $M$, Millis R, Peters G, et al. (1996) Cyclin DI and prognosis in human breast cancer. Int. J. Cancer 69: 92-99.

24. Schuuring E. (1995) The involvement of the chromosome 11 q13 region in human malignancies: Cyclin D1 and EMS are two new candidate oncogenes-a review. Gene 159: 83-96.

25. Bartkova J, Zemanova M, Bartek J. (1996) Abundance and subcellular locilisation of cyclin D3 in human tumours. Int. J. Cancer 65: 323-327.

26. Chen J, Milo GE, Shuler CF, Schuller DE. (1996) Xenograft growth and histodifferentiation of squamous cell carcinomas of the pharynx and larynx. Oral Surg. Oral Med. Oral Pathol. Oral Radiol. Endodont. 81: 197202.

27. Milo GE, Trewyn RW. (1982) In vitro transformation of cultured human diploid fibroblasts. In: Banbury Report, Vol. 12. Cold Spring Harbor Laboratory, Cold Spring Harbor, NY, pp. 3-13.

28. Yohn J, Lehman TA, Kurian P, Ribovich $M$, Milo GE. (1988) Benzo[a]pyrene diol epoxide I modification of DNA in human skin xenografts. J. Invest. Dermatol. 91: 363-368.

29. Wani G, D'Ambrosio SM. (1995) Differential expression of the $\mathrm{O}^{6}$-ATase gene in normal human breast and skin tissue: In situ mapping of cell type specific expression. Mol. Carcinog. 12: 177-184.

30. Shan-Rong S, Key ME, Kalra KL. (1991) Antigen retrival in formalin-fixed, paraffinembedded tissues: An enhancement method for immunohistochemical staining based on microwave oven heating or tissue sections. J. Histochem. Cytochem. 39: 741-748.

31. Allred DC, O'Connell P, Fuqua SAW, Osborne CK. (1994) Immunohistochemical studies of early breast cancer evolution. Breast Cancer Res. Treat. 32: 13-18.

32. Ozzello L, De Rosa CM, Cantell K, Kauppinen HL, Habif DV, Sr. (1995) Regression of human breast cancer xenografts in response to intralesional treatment with interferons $\alpha$ and $\gamma$ potentiated by tumor necrosis factor. J. Interferon Cytokine Res. 15: 839-848. 
33. Gottlieb TM, Oren M. (1996) p53 in growth control and neoplasia. Biochim. Biophys. Acta Rev. Cancer 1287: 77-102.

34. Carson DA, Lois A. (1995) Cancer progression and p53. Lancet 346: 1009-1011.

35. Pujol P, Hilsenbeck SG, Chamness GC, Elledge RM. (1994) Rising levels of estrogen receptor in breast cancer over 2 decades. Cancer 74: 1601-1606.

36. Clarke R, Skaar T, Baumann K, Leonessa F, James M, Lippman J, et al. (1994) Hormonal carcinogenesis in breast cancer: Cellular and molecular studies of malignant progression. Breast Cancer Res. Treat. 31: 237-248.

37. Nagai MA, Marques LA, Yamamoto L, Fujiyama CT, Brentani MM. (1994) Estrogen and progesterone receptor mRNA levels in primary breast cancer: Association with patient survival and other clinical and tumor features. Int. J. Cancer 59: 351-356.

38. Makris A, Powles TJ, Dowsett M, Allred C. (1995) p53 protein overexpression and chemosensitivity in breast cancer. Lancet 345: 1181-1182.

39. Lipponen $\mathrm{P}, \mathrm{Ji} \mathrm{H}$, Aaltomaa $\mathrm{S}$, Syrjänen $\mathrm{S}$, Syrjänen K. (1993) p53 protein expression in breast cancer as related to histopathological characteristics and prognosis. Int. J. Cancer 55: 51-56.

40. Friedrichs $\mathrm{K}$, Gluba S, Eidtmann $\mathrm{H}$, Jonat W. (1993) Overexpression of $\mathrm{p} 53$ and prognosis in breast cancer. Cancer 72: 3641-3647.

41. Martinazzi M. (1994) Expression of p53 oncoprotein in different histological types of breast carcinoma. Am. J. Pathol. 144: 205.

42. Merlo GR, Venesio T, Taverna D, Marte BM, Callahan R, Hynes NE. (1994) Growth suppression of normal mammary epithelial cells by wild-type p53. Oncogene 9: 443-453.

43. Smith HS, Lu Y, Deng G, Martinez O, Krams S, Ljung B-M, et al. (1993) Molecular aspects of early stages of breast cancer progression. $J$. Cell. Biochem. 53(Suppl. 17G): 144-152.

44. Elledge RM, Allred DC. (1994) The p53 tumor suppressor gene in breast cancer. Breast Cancer Res. Treat. 32: 39-47.

45. Katoh A, Breier S, Stemmler N, Specht S, Blanock K, D'Amico F. (1996) p53 protein expression in human breast carcinoma: Lack of prognostic potential for recurrence of the disease. Anticancer Res. 16: 1301-1304.
46. Barbareschi M, Caffo O, Doglioni C, Fina P, Marchetti A, Buttitta F, et al. (1996) p2 $1^{\text {WAF1 }}$ immunohistochemical expression in breast carcinoma: Correlations with clinicopathological data, oestrogen receptor status, MIBl expression, p53 gene and protein alterations and relapse-free survival. $B r . J$. Cancer 74: 208-215.

47. Singleton TP, Strickler JG. (1992) Clinical and pathological significance of the c-erbB-2 (HER-2/neu) oncogene. Pathol. Ann. 1: 165190.

48. Hurst J, Maniar N, Tombarkiewicz J, Lucas F, Roberson C, Steplewski Z, et al. (1993) A novel model of a metastatic human tumor xenograft line. Br. J. Cancer 68: 274-276.

49. Symmans WF, Liu J, Knowles DM, Inghirami G. (1995) Breast cancer heterogeneity: Evaluation of clonality in primary and metastatic lesions. Hum. Pathol. 26: 210-216.

50. Allred DC, O'Connell P, Fuqua SAW. (1993) Biomarkers in early breast neoplasia. J. Cell. Biochem. 53(Suppl. 17G): 125-131.

51. Szöllösi J, Balázs M, Feuerstein BG, Benz CC, Waldman FM. (1995) ERBB-2 (HER2/ neu) gene copy number, $\mathrm{p} 185^{\mathrm{HER}-2}$ overexpression, and intratumor heterogeneity in human breast cancer. Cancer Res. 55: 54005407.

52. Stanton PD, Cooke TG, Forster G, Smith D, Going JJ. (1996) Cell kinetics in vivo of human breast cancer. Br. J. Surg. 83: 98-102.

53. Han EK-H, Sgambato A, Jiang W, Zhang Y-J, Santella RM, Doki Y, et al. (1995) Stable overexpression of cyclin Dl in a human mammary epithelial cell line prolongs the S-phase and inhibits growth. Oncogene 10: 953-961.

54. Sgambato A, Han EKH, Zhang YJ, Moon RC, Santella RM, Weinstein IB. (1995) Deregulated expression of cyclin Dl and other cell cycle-related genes in carcinogen-induced rat mammary tumors. Carcinogenesis 16: 2193-2198.

55. McIntosh GG, Anderson JJ, Milton I, Steward M, Parr AH, Thomas MD, et al. (1995) Determination of the prognostic value of cyclin Dl overexpression in breast cancer. Oncogene 11: 885-891. 